\title{
Does the Spanish 15M have an ideology? Issues of Method And MEASUREMENT ${ }^{1}$
}

\author{
¿Tiene el 15M una IDEOLOGía? Cuestiones de MÉTODO Y MEDIDA
}

Rubén Díez García

Carlos III University of Madrid; Complutense University of Madrid;

Historia editorial
Recibido: 14-08-2013
Aceptado: 17-04-2014

\section{Keywords}

Collective identity Ideology

Indignados

Methodology

New Left

Social movements

Spanish $15 \mathrm{M}$

\begin{abstract}
The broad aim of this paper is to look into the implications of applying two different methods of research and analytical assumptions to the study of social movements. In order to develop and discuss this aim, I focus my analysis on the emergence of a social movement that impacted Spanish society in 2011: the 'indignados' movement 15M. Particularly, in this case, I confront the main conclusions of two different methodological approaches that analyze the emergence of the movement, focusing my interest in the ideological roots of its collective identity. The first approach is mainly based on ethnographic data (Laraña \& Díez, 2012a; 2012b) and the second one consists of a statistical macro-analysis. Whereas in the two first works we highlighted the most micro and intersubjective aspects of the social action, through ethnographic techniques, that allowed us to study how the activists organize the actions of the movement, spread their frames and construct its collective identity, this paper mainly focuses on macro statistical data in order to: i) analyze the ideological bases of the movement, ii) compare the results obtained regarding this issue from the both aforementioned approaches, and iii) look at their complementarities.
\end{abstract}

\section{Resumen}

Palabras clave Identidad colectiva Ideología Indignados Metodología Nueva Izquierda Movimientos Sociales $15 \mathrm{M}$

El objetivo de este texto es aproximarse a las implicaciones de utilizar dos métodos de investigación y supuestos analíticos diferentes al estudio de los movimientos sociales. Para desarrollar y discutir este aspecto, me centro en el análisis de la emergencia de un movimiento social que impactó a la sociedad española en 2011: el movimiento $15 \mathrm{M}$ de los indignados. Particularmente confronto las principales conclusiones de dos aproximaciones metodológicas que analizan su emergencia, centrando mi interés en las raíces ideológicas de su identidad colectiva. La primera aproximación tiene su base primordialmente en datos etnográficos (Laraña y Díez, 2012a; 2012b) y la segunda utiliza datos estadísticos agregados. Mientras que en trabajos previos hemos destacado los aspectos más micro e intersubjetivos de la acción social, mediante la utilización de técnicas etnográficas, que nos permitieron estudiar cómo los activistas organizan las acciones del movimiento, difunden sus marcos y construyen su identidad colectiva, este texto se centran en datos agregados de origen estadístico con el objetivo de: i) analizar las bases ideológicas de este movimiento, ii) comparar los resultados obtenidos en relación a esta cuestión desde las aproximaciones anteriormente mencionadas, y iii) hacer notar sus complementariedades.

Díez García, Rubén (2014). Does the Spanish 15M have an ideology? Issues of method and measurement. Athenea Digital, 14(3), 199-217. http://dx.doi.org/10.5565/rev/athenea.1252

\footnotetext{
1 This paper is part of my thesis work at the University Complutense of Madrid. I would like to thank Professor Enrique Laraña for guiding and supporting me in my projects and thesis all these years. I would also thank to the anonymous reviewers of Athenea Digital and Dr. Laurence Cox (National University of Ireland) for their valuable comments and suggestions, and Patricia Gutierrez Sierra for her corrections on the draft version of this document. She is Anthropologist and Master in Conflict Analysis \& Resolution by the George Mason University and the University of Malta.
} 


\section{Introducción}

The study of issues related to social participation and collective action has generated diverse trends of analysis ${ }^{2}$, and several academics and researchers have dealt with methodological and epistemological questions concerning the study of social movements $^{3}$. In this paper I focus on how issues of method and measurement directly affect the results of the sociological research (Cicourel, 1964). This is a matter that provokes different interpretations and approaches, particularly when social scientists focus on the study of the intersubjective contexts of the social action, as was discussed by Max Weber.

The broad aim of this paper is to look into the implications of applying two different methods of research and analytical assumptions to the study of social movements. In order to develop and discuss this aim, I focus my analysis on the emergence of a social movement that impacted Spanish society in 2011: the 'indignados' movement 15M. Particularly, in this case, I confront the main conclusions of two different methodological approaches that analyze the emergence of the movement, focusing my interest in the ideological roots of its collective identity. The first approach is mainly based on ethnographic data (Laraña \& Díez, 2012a; 2012b) and the second one consists of a statistical macro-analysis.

My starting assumption is that certain participatory forms and intermediate groups" ${ }^{\prime}$, such as associations, non-profit organizations or social movement organizations, are capable of generating social controversies, public debates and promoting mobilizations. These are forms of participation and social organizations, with a high potential to produce reforms or to resist them, which are playing a main role in the processes of modernization and social change in Spain (Laraña, 2007).

Although social organizations differ from social movements in their structure, operation and actions (Laraña, 1999), citizens joining social organizations and groups with power of collective persuasion offer a high potential to integrate and engage in social movements. Social movements that are able to guide and channel collective ac-

\footnotetext{
${ }^{2}$ Resource mobilization theory (Zald \& McCarthy, 1987), political opportunity theory (Tarrow, 1994; Tilly, 1991), political culture (Almond \& Verba 1963; Inglehart 1991; Putnam 2000) or social constructionist and collective identities theories (Snow \& Benford 1988; Eyerman \& Jamison 1991; Gusfield 1994; Melucci 1989; Laraña 1999).

3 For instance, Alberto Melucci in the Appendix of Nomads of the present (1989); Mario Diani \& Ron Eyerman in Studying collective action (1992); Enrique Laraña in La construcción de los movimientos socials (1999); Bert Klandermans \& Suzanne Staggenborg in Methods of social movement research (2002); or most recently, David Croteau, William Hoynes \& Charlotte Ryan in Rhyming Hope and History: Activists, Academics and Social Movement Schol$\operatorname{arship}(2005)$.

4 As Durkheim discussed in The Division of Labor in Society (1893/2001), in modern societies the "intermediate groups" mediate between the individual sphere, -including the primary groups of reference-, and the institutions of the State, whose decisions affect people's lives.
} 
tion in i) scenarios of civic confrontation in which some policies are perceived as unfair, or ii) scenarios in which the legitimacy of a particular state of affairs is controversial.

Social movements may play a significant role in these scenarios, diagnosing causes (diagnostic framing) and suggesting solutions (prognostic framing), and also calling citizens to action promoting demonstrations and mobilizations (motivational framing) (Snow \& Benford, 1988). Furthermore, it should be taken into account that support to these actions is maintained, throughout time, by citizens and "intermediate groups" in a wide net of social relationships and under a process of convergence and integration between them and social movements, in which the net of social relationships shaped can be: i) either interpersonal or inter-groups; ii) either real and physical or virtual and online (Belli \& Díez, 2013); iii) either latent or visible (Melucci, 1989) to the eye of the researcher.

This net of relationships, involving any sort of social interaction, provides meaning to the actions of the activists and supporters, who perform diverse activities by which social movements construct their collective identity (Melucci, 1995). All this occurs in a process of reflexivity (Gusfield, 1994) that confers on them a capacity to create new collective meanings, symbols and values. Thus, "in attending to movements, members of a society recognize that social rules are at issue" (Gusfield, 1994, p. 69).

Although these activities are latent many times, they are not less important for social movements to achieve their goals. Such activities are not necessarily carried out by activists in visible actions of protest or mass mobilizations. For instance: i) more or less informal meetings and workshops; ii) assemblies or joint activities inter-groups in an establishment or in the streets; iii) working meetings between representatives of different social organizations and groups, (either face-to-face or via videoconference and other networking platforms). Likewise, it could be the sharing of messages and claims via social networks, such as Twitter and Facebook, or the coordination between activists through forums and interactive platforms on the web.

The concepts of latency and visibility (Melucci, 1989) explore two interrelated and dynamic poles of the social movements. Those social scientists that restrict their observations exclusively to the most visible protests and demonstrations, or to statistical indicators on associational involvement and participation in collective actions, should take into account that social movements' organizations are inspired by the everyday production of alternative meaning frames ${ }^{5}$. These social 'frames of reference' (Goffman,

\footnotetext{
This concept comes from Goffman and refers to "an interpretative schemata which simplifies and condenses the 'world out there' by selectively punctuating and encoding objects, situations, events, experiences, and sequences of action within one's present or past environment” (Snow \& Benford, 1992: 137).
} 
1974) serve the purpose of articulating the reflexivity (Gusfield, 1994) and collective identity (Melucci, 1995) of the social movements, as well as their mobilization frames (Snow \& Benford, 1988) that are spread to public opinion and the citizenship, not only in meetings and publics acts, but also on the web.

The 'invisibility', or 'not quantification', of certain forms of social participation is not a sign of 'demobilization' or inactivity. In fact, the potential and strength of a social movement is built on everyday interaction processes through nets of social relationships between citizens, 'intermediate groups' and organizations of social movements throughout time.

The ability to participate has been shown by the citizens of this country in the great demonstrations held since the mid 1990s and continues to be seen nowadays in the actions of the 'indignados' movement (Laraña, 2007; Laraña \& Díez, 2010, 2012a, $2012 \mathrm{~b}, 2013)$. We also suggest that Spanish civil society is more open and more active every time because of the participation of the citizens in less visible spheres, away from the formal politics, such as the actions of solidarity and cooperation, and the association in the defense of interests ${ }^{6}$. These values are extolled by Alexis de Tocqueville in his work on Democracy in America (1840/1985) as essentials to defeat despotism and achieve democratic freedom: the vitality of the civil society and the civic virtues.

\section{Two different methodological approaches}

Grounded in these assumptions and ethnographic data, in the aforementioned works we have analyzed the most characteristic and relevant aspects in the emergence of the $15 \mathrm{M}$ movement, such as, its mobilization frames (Snow \& Benford, 1988), its transversal character which cuts across different ideologies, its demand of political regeneration, its audacious use of information technologies and its internal organization (Laraña \& Díez, 2012a). Likewise, on its first anniversary we confirmed some of our first conclusions. Emphasizing that, after a year of existence, it continued to be very active and dynamic in its forms and maintained its mobilization frames, as well as its power of collective persuasion in Spanish society and in the international sphere (Laraña \& Díez, 2012b). Moreover, we referred to the need to go beyond the politicalprofessional point of view (Melucci, 1989) and the discourse about the analytical categories of 'left' and 'right', in the study of this kind of social processes ${ }^{7}$.

\footnotetext{
${ }^{6}$ Digital Communication Technologies have played an important role given that the Internet and social networks like Twitter and Facebook favor this. This trend is also observable in other cases (Castells, 2009; 2012).

7 This point of view "explains social movements from the traditional dichotomy between emotional and rational factors and classifies them according to the predominance of one or another. [This view] is very influential in
} 
In both cases, we mainly used ethnographic techniques such as participant observation; the registration of pictures, banners and photos; the recording of meetings and activists' interventions; brief interviews in the context of the social action and the review of documentation produced by the movement and press coverage. This material allowed us to analyze the discourse of the activists, demonstrators and participants in the actions and activities organized by the movement. The data collection and the fieldwork took place mainly in the spring of 2011 and 2012, although it has kept on throughout time, with a lower regularity, by attending several public activities of the movement and actions, independently of their grade of visibility. However, it should be taken into consideration that the statistical data included in this paper are temporarily limited from May 2011 to the first fifteen days of $2012^{8}$.

On this occasion I incorporate another sort of data. Whereas in the two first works we mainly highlighted the most micro and intersubjective aspects of the social action, through ethnographic techniques, that allowed us to study how the activists organize the actions of the movement, spread their frames and construct its collective identity, this paper mainly focuses on macro statistical data in order to: i) analyze the ideological bases of the movement, ii) compare the results obtained regarding this issue from the both aforementioned approaches, and iii) look at their complementarities.

\section{The ideological bases of the $15 \mathrm{M}$ movement}

In our previous work (2012b) we highlighted the widespread presence of a taxonomic discourse that uses categories and labels, such as 'left' and 'right' or 'conservative' and 'progressive', "whose semantic grounds are related to the aforementioned politicalprofessional's point of view" (Laraña \& Díez, 2012b, p. 216). These common categories in Spanish politics and media, are used to label "a movement's ideology, a public policy or a person who applies it, according to a binary code which alludes to values considered as correct or incorrect and discredits a person or group basing on it" (2012b). However, as I try to show in this paper, it seems that the ordinary use of such "mainstream" set of categories can neither account for the plural and transversal character of this movement, nor for its inclusiveness and hybrid identity.

\footnotetext{
Spain and has promoted some assumptions about the 15M nature that we challenge" (Díez \& Laraña, not published).

8 The data used come from a survey, based on a national representative sample of more than 6,000 individuals, which the Centro de Investigaciones Sociológicas (CIS) carried out between the months of November 2011 and January 2012 (CIS, ES2920, 2011). This survey included the following question: "Since May 2011, ihave you participated in any of the demonstrations, camps, marches or protests of this movement?" (ES2920, Q.22a, author's translation). Thus, the statistical data are limited to these dates and make reference to 595 individuals who affirmed that they had participated in these actions.
} 


\begin{tabular}{lcc}
\hline Label & $\mathbf{1}^{\text {st }}$ choice & $2^{\text {nd }}$ choice \\
\hline Socialist & 19,02 & 7,85 \\
Liberal & 15,88 & 6,83 \\
DN/NA & 13,87 & 48,37 \\
Social Democrat & 11,95 & 5,71 \\
Ecologist & 9,54 & 14,58 \\
Other answers & 7,31 & 2,86 \\
Nationalist & 5,37 & 3,31 \\
Communist & 4,78 & 2,38 \\
Feminist & 4,21 & 6,47 \\
Conservative & 3,61 & 1,04 \\
Apolitical & 2,25 & 0,14 \\
Christian Democrat & 2,21 & 0,45 \\
\multicolumn{1}{c}{$\mathbf{N}$} & $\mathbf{5 9 5}$ & $\mathbf{5 9 5}$ \\
\hline
\end{tabular}

Table 1. How the participants in the movement define themselves politically (Percentages). Source: CIS, ES2920, 2011.
Given its widespread presence, I have analyzed some data from the above cited survey (CIS ES2920, 2011) that contributes to a broader understanding of the movement's ideological bases. Although this study carried out by the CIS includes its traditional ten point 'left-right' scale', it also includes a question regarding 'how respondent defines himself politically', according to a classification of labels ${ }^{10}$. In addition, the respondent is asked to select a second choice among this same classification (see Table 1).

Taking into consideration the first choice of those who participated in the actions of the movement in 2011, the percentages distribution shows: i) a high level of disparity among respondents, and ii) higher percentages in labels whose ascription to the political spheres of 'left' and 'right' is, at least, controversial, such as 'liberal' (15.88\%) and 'ecologist'

(9.54\%). Likewise, the percentages of those who did not answer and did not know added up to $13.87 \%$, the most frequent category after 'socialist' $(19,02 \%)$ and 'liberal'. In the second choice, the sum of the percentages for 'do not know' and 'no answer' represented almost 1 of every 2 respondents (48.37\%). After these, the label 'ecologist' was the second with a higher percentage (14.58\%).

These data seem to confirm the transversal and plural character of this movement, as well as its capacity to go beyond the dichotomous labels of 'left' and 'right' or 'progressive' and 'conservative' (2012b, p. 217).

However, the use of such categories also presents methodological challenges. These data should be interpreted with caution since these labels do not have a univocal meaning, and their meaning may vary substantively across individuals (Cicourel, 1964; Laraña, 1999, p. 334). Thus, we cannot take for granted the meaning of categories used in sociological research to analyze reality and it is necessary to know how individuals talk and write about them (1999), in order to understand the meaning that these individuals attribute to them.

\footnotetext{
"In political matters, people usually use the expressions left and right. How would you place your view on this scale? Left (01), Right (10), DK (98), NA (99)”. (ES2920, Q.40, author's translation). The mean score of the participants in the actions of the movement is 3.56, and the standard deviation 1.75 .

${ }^{10}$ Conservative; Christian Democrat; Liberal; Social Democrat; Socialist; Communist; Nationalist; Feminist; Ecologist and Other.
} 


\section{Issues on method and ideology}

Following that common taxonomic approach, several studies have made use of such categories (Calvo, Gómez-Pastrana, Jiménez \& Mena, 2011; Chaves, 2012; Likki, 2012) that, given its low interpretative potential, clash with the ideological pluralism of this movement (Laraña \& Díez, 2012b). For instance, the cited studies point out that the ideological identities of the activists and participants are grounded in the Left ${ }^{11}$. Such assertion is particularly based on the analysis of data obtained from a traditional ten point 'left-right' scale ${ }^{12}$.

However, it should be taken into consideration that the concept of ideology, according to Karl Mannheim (1936/1954, p. 49), consists of two different conceptions. Both are grounded in the distrust regarding what the other, as political opponent, says or argues. This does not allow "to reach an understanding of his real meaning and intention", putting the individual aside and trying to understand "what is said by the indirect method of analyzing the social conditions of the individual or his group" (1936/1954, p. 49).

In contrast, we emphasize the importance of the microsociological context and the need to understand what people are saying and arguing, without ignoring the validity of thought of those with different ideas. An attitude and a way of thinking and acting, that, in fact, the activists and participants of the movement themselves put into practice in their assemblies and meetings, providing the movement with a high level of reflexivity (Gusfield, 1994).

Following Mannheim, the 'particular' conception of ideology "denotes that we are sceptical of the ideas and representations advanced by our opponent" (1936/1954, p. 49), and it is related with other sociological approaches focuses on analyze the aforementioned 'frames of reference', as interpretative schemata which people use to simplify and condense social life (Goffman, 1974). For instance, in our everyday social life, when we talk about political matters, we frequently use the notions 'left' and 'right' in order to interpret others' ideas. Thus, when people share a common ideology, "they can discuss and debate social issues with a reasonable degree of mutual understanding” (Turner, 1994, p. 80).

\footnotetext{
11 "The ideological identities are well defined towards the left" (author's translation, Calvo et al., 2011, p. 8); "15M activists in Madrid locate themselves clearly on the left of the political left-right continuum" (Likki, 2011, p. 6); "15M participants define and recognize themselves clearly as left-wing" (author's translation, Chaves, 2012, p. 9).

${ }^{12}$ Their conclusions are mainly based on two surveys carried out in Salamanca and Madrid to a sample of activists and participants in the actions of the movement in each city. Likewise, these studies support their conclusions in data from the ten points 'right-left' scale included in the CIS survey, (CIS, ES2920, 2011).
} 
However, in surveys, respondents usually have to indicate on a scale where they place themselves between both extremes. The aggregate data obtained allows analysts to deduce, through a statistical indicator, the average ideological position of particular groups or collectives. Thus, this procedure allows analysts to establish conclusions regarding the ideology of these groups. But they are also jumping from a 'particular' conception of ideology to a 'total' one. In this regard, although some analysts, politicians and journalists have described the $15 \mathrm{M}$ as a leftist movement, one of the most important organizations of this movement since its emergence in 2011, Real Democracy Now! (Democracia Real Ya! - DRY) ${ }^{13}$, claims:

We are ordinary people. We are like you: people, who get up every morning to study, work or find a job, people who have family and friends. People, who work hard every day to provide a better future for those around us. Some of us consider ourselves progressive, others conservative. Some of us are believers, some not. Some of us have clearly defined ideologies, others are apolitical, but we are all concerned and angry about the political, economic, and social outlook which we see around us: corruption among politicians, businessmen, bankers, leaving us helpless, without a voice (DRY, 2011, paragraph 1$)^{14}$.

Moreover, it seems that in 2013 this 'political agenda' has continued to be shared by several researchers, key activists and supporters of the movement $15 \mathrm{M}$ as I could see for myself during the meeting \#15MP2P in July $2013^{15}$. From the $4^{\text {th }}$ to the $5^{\text {th }}$ of July, hashtag \#15MP2P became a trending topic on Twitter in Spain since participants and cyberactivists tweeted thousands of messages regarding the issues tackled in that meeting (Almeida, 2013a). In fact, several tweets spoke about the inclusive, transversal and plural character of this movement as was revealed in the encounter ${ }^{16}$. Particularly, that this movement and its related organizations, such as the Platform of People Affected by Mortgages (Plataforma de Afectados por la Hipoteca - PAH) ${ }^{17}$, place them-

${ }^{13}$ However it seems that this organization has lost some of its influence on the movement. It underwent an internal division and in April 2012 some of its members founded the Association 'Real Democracy Now' (www.asociaciondry.org), while others maintained the original organization (www.democraciarealya.es).

${ }^{14}$ During the movement demonstrations it was also possible to observe the refusal of the participants to identify themselves following these labels (Gener, 2011; LaEneida, 2011; Rey, 2011).

${ }^{15}$ The \#15MP2P (Papers\&Productions) Conferences took place from $3^{\text {rd }}$ to $5^{\text {th }}$ of July 2013 in Barcelona. This was a transdisciplinary meeting dedicated to the $15 \mathrm{M}$ movement organized by the IN3 research program in Communication and Civil Society of the Open University of Catalonia (UOC). This program is coordinated by sociologist Manuel Castells and very well known activists, supporters of this movement, scholars and researchers participated in the meeting (\#15MP2P, 2013).

${ }^{16}$ Klaudia Álvarez \& Dario Lovaglio (2013), Amador Fernadez-Savater (2013b), Simona Levi (2013), Josep Lobera \& Victor Sampedro (2013), Nico Sguiglia (2013) or Guillermo Zapata (2013), among others.

${ }^{17} \mathrm{http}: / /$ afectadosporlahipoteca.com. This organization started in Barcelona in February 2009 and demands the cancellation of those mortgages that could not be paid, thus allowing donation as payment, given that the banks still accumulate thousands of empty houses which are not fulfilling its social function. It has been one of the most ac- 
selves beyond the political categories of 'left' and 'right' (Almeida, 2013a; Joan, 2013; Tecnopolítica, 2013a, 2013b; Toret, 2013). This fact, however, does not prevent activists, groups and organizations from recognizing and vindicating the influence of different activist traditions and ideological backgrounds in accordance with the plural character of the movement.

Regarding this issue, in an interview to El País, Ada Colau, one of the most influential activists and spokeswoman of the PAH, said in July 2013 that she does not define herself as leftist. In contrast, she defines herself as a radical democrat and a defender of human rights. She also argues that:

\begin{abstract}
It is necessary a democracy, but a real one, not a democracy kidnapped as it is now. Left and right have been useful during a long time, but I think that nowadays there is a social majority that does not identify itself with these labels. Parties have seriously hurt its own image: the PSOE has smashed the idea of the Left in this country. In themes of civil rights and liberties, I recognize myself more in a left-wing tradition, but I do not identify myself with the current representation (López Iturriaga, 28/07/2013, paragraph 47; author's translation).
\end{abstract}

On the other hand, Karl Mannheim's 'total' conception of ideology refers "to the ideology of an age or of a concrete historic-social group, e.g. of a class, when we are concerned with the characteristics and composition of the total structure of the mind of this epoch or of this group" (1936/1954, p. 49). Frequently, those who follow a political-professional point of view unequivocally connect the belonging to a certain group or collective, and the whole collective itself, with a particular ideology. But, consequently, they are accepting that the perspective or viewpoint of an individual is mainly due to and determined by his belonging to a particular analytical category of reference, such as a social group, epoch or class.

In this sense, the aforementioned studies (Calvo et al., 2011 and Likki, 2012), as well as the data from the CIS survey, point out that some respondents declined to place themselves in a particular ideological position, according to this scale, even when they were encouraged to do it. Among the participants of this movement, those who did not know or did not answer represented the $6 \%$ in the CIS survey, and $12 \%$ in the other two surveys (Salamanca and Madrid). Among the citizens who did not participate in the actions organized by the movement, $15 \%$ declined to place themselves in an ideological position, according to the CIS survey (CIS, ES2920, 2011). 
These differences between percentages may be attributed to the design of the statistical samples and the accomplishment of these surveys. The survey carried out by the CIS is based on a national representative sample of more than 6,000 individuals, of which 592 participated in the actions organized by the movement from May 2011 to January 2012. In contrast, the surveys carried out in Salamanca and Madrid consist of two smaller sample sizes, leading to data with different characteristics, which however does not mean a lack of neither quality nor reliability.

The Madrid survey collected data from 230 individuals "who participated in activities of the $15 \mathrm{M}$ movement in Madrid in November 2011. The majority had participated in the demonstrations on both May 15 and October 15 in 2011. Furthermore, 90\% had participated in assemblies" (Likki, 2012, p. 3). In Salamanca the data came from 250 individuals and were collected between the $26^{\text {th }}$ and the $30^{\text {th }}$ of May 2011. They had participated in the $15 \mathrm{M}$ camp in the Constitución Square and had attended assemblies organized throughout these days (Calvo et al., 2011, p. 5) ${ }^{18}$.

\section{Some conclusions}

As I have shown, the aggregate data considered allowing the development of two different explanations about the ideological bases of the 'indignados' collective identity in Spain. If we focus on the results obtained through the ten point scale of ideology, it is easy to conclude that this movement is placed in the left. In contrast, according to Table 1 and our previous works, this movement shows an ideological pluralism and a transversal character that contrasts with the interpretations given from the politicalprofessional perspective. Supporters of the Spanish 15M consider themselves a social movement of persons, instead of activists or militants (Perugorría \& Tejerina, 2013) which are terms associated "to the 'old way of doing politics' (la 'vieja política'), based on ideological or partisan affiliations" (Perugorría \& Tejerina, 2013, p. 10). Moreover these traits are also present in other social movements that have emerged since the Arab Spring, such as Occupy Wall Street (OWS): a movement of people that appeals to different political orientations (Cordero-Guzman 2011; Milkman, Luce \& Lewis, 2013, p. 13). Indeed, Hector Cordero-Guzman (2011), according to a survey of 1.619 activists and supporters who completed a questionnaire in the 'occupywallstreet' web site, suggests that "the 99\% movement comes from and looks like the 99\%" (Cordero-Guzman, 2011a) ${ }^{19}$.

\footnotetext{
${ }^{18}$ The mean scores of ideology obtained in these studies are: Madrid, November 2011, 1.67 (Calvo et al., 2011); Salamanca, May 2011, 2.84 (Likki, 2011); CIS, May 2011 - January 2012, 3.56 (CIS, ES2920, 2011). Those who did not participate in the actions organized by the movement scored 5.06, according to the CIS.

19 '70\% of \#OWS Supporters are Politically Independent' (Cordero-Guzman, 2011b).
} 
According to our ethnographic data and our analyses, we have emphasized the relationship of continuity between the $15 \mathrm{M}$ and the American New Left of the 1960s, with whom the 'indignados' share some goals and common traits, such as its non-violent character and its demand of a 'participatory democracy'20 (Díez, 2013; 2014; Laraña \& Díez, 2012a). After all, and broadly speaking, the Spanish 15M, as well as other movements in the current wave of global indignation, deals with some traditional themes of that New Left. In essence, and from a perspective anchored in globalization and digital communication technologies, it seems that the \#15M, \#OccupyWallStreet (Langman, 2013) or the \#BRevolution in Brazil (Gutierrez, 2013a; 2013b; Neaera, 2013), among others, share common traits with the New Left (e.g. its pluralism) and also tackle similar issues, for instance: i) "the distrust of state power, parties, competition, leadership, bureaucracies, and, finally, representative government" (Caute, 1988, p. 33); ii) the equality of opportunities and civil rights (1988); iii) the rejection of political and economic concentrations of power (1988); or iv) the pacifism, the opposition to multinational corporations, the criticism of economic growth and the "participatory rather than representative democracy" (Turner, 1994, p. 91) ${ }^{21}$.

In the Spanish case, the empirical evidence included in this paper seems to support part of this interpretation, given that the statistical aggregate data confirm its ideological pluralism (Table 1) and its call for more participatory forms of democracy (ES2920 Q.18, in footnote 19), but also seem to point to the leftist background of some of its activists, according to the ten point ideology scale (ES2920 Q.40).

The meaning that we attribute to political categories differs from the uses of such categories that we commonly find in the media and the press. These categories offer the advantage of allowing us to place social organizations and social movements in a scheme of classification that simplifies its complexity, and also are useful in order to analyze electoral results (Laraña \& Díez, 2012a, p. 126). However, as it usually happens with analytical typologies, reality is more complex and it can include features from many concepts and schemes that we use to categorize reality. A fact informed by Goffman (1961) regarding the concept of total institution.

\footnotetext{
${ }^{20}$ According to a scale from 0 to 10 included in the CIS survey (CIS, ES2920, 2011, Q. 18) those who participated in the actions organized by the movement were inclined towards more participatory forms (3.85), rather than a pure representative democracy (10). Those who did not participate scored 4.94 (statistically significant differences according $t$-test, $\mathrm{p}<0.05)$. In this scale 0 means that "political decisions should be taken directly by citizens" and 10 means that "political decisions should be taken directly by politicians".

${ }^{21}$ Concerning this point it should be noted that this interpretation can be rendered problematic because of the gap between the specific data presented in this paper and the macro-historical reflection based on Turner's and Caute's works and related to different contexts and historical periods. In these sense, it would be useful to integrate in future analysis a historical approach (Díez, 2013; 2014). Given the particular issue tackled in this paper and for reasons of space I do not dealt with it in detail and I can only point out general trends in this regard. For the Spanish case see Enrique Laraña, 2011, Los movimientos sociales y la transición a la democracia en España.
} 
Following Alberto Melucci (1995, p. 51) these categories function as "an analytical tool, not a datum or an essence, not a 'thing' with a real existence. [...] one should never forget that we are not talking of 'reality', but of instruments or lenses through which we read reality". Thus, these analytical typologies are only useful "if it helps to analyze phenomena, or dimensions of them, that cannot be explained through other concepts or models and if it contributes to new knowledge and understanding of these phenomena" (1995).

In this line of work, we emphasize that such categories have lost their usefulness to understand a social movement characterized by: i) the refusal to define itself as left or right wing; and ii) the demand of alternative participatory forms that go beyond the formal politics and the political parties who define themselves with these kinds of categories (Laraña \& Díez, 2012a; 2012b). Likewise, the qualitative data collected and analyzed in the study carried out by Tiina Likki in Madrid, leads her to point out the "need to go beyond a traditional conceptualization of ideology in terms of left and right” (2012, p. 13) ${ }^{22}$.

All things considered, in the Spanish case the ethnographic and statistical evidence seems to point to an ideological background mainly characterized by i) its pluralism (Table 1) and ii) its call for 'participatory democracy' based on non-violence. But, also, by iii) certain traits traditionally connected, in Spain, with the non-institutional left. As well as, in higher or lower degree, traits connected to other backgrounds and activist traditions, such as alter-globalization, cyberactivism and hacktivism, anarchism (autonomous self-organization, self-managed social centers and occupation), pacifism, feminism, civil rights (i.e. immigrants and LGTB) and social disobedience, environmentalism, student activism, liberal humanism or neighborhood movements. This fact became clear during the meeting \#15MP2P (2013), given that one of the most repeated traits about the movement, shared and generally accepted by researchers, activists and supporters, pointed to the $15 \mathrm{M}$ as a kind of hybrid form ${ }^{23}$.

\footnotetext{
22 "For some participants, the $15 \mathrm{M}$ is first and foremost a movement of citizens against politicians and banks. Divisions in terms of left and right were seen as diverting attention away from more real and pressing concerns such as human dignity" (Likki, 2012, p.13). I have also planned to incorporate into my research this sort of qualitative data from a study carried out by the CIS (CIS, ES2920, 2011), consisting of 10 in-depth interviews with activists, supporters and sympathizers, and 8 focus groups.

${ }^{23}$ A potential unintended consequence of this hybrid composition is conflict arising and dissent due to the divergences, discrepancies and tensions that take place between social actors with different frames of meaning, inter ests, priorities and backgrounds. At another level of analysis, authors such as Michael Hardt \& Antonio Negri (2000; 2004) or Paolo Virno have developed an interesting discussion, -based on post-Marxist ideas and $\mathrm{Au}$ tonomist Marxism-, on the 'new figures of struggle' and the concept of multitude, as a global, hybrid, and mutant "new social class that removes itself from nations and parties to meet head on the challenge" of global ruling powers (Virno, 2004, p. 14).
} 
In fact, it seems that the major unions and traditional left parties in Spain "have lost its ideological hegemony, which would have passed on to the hands of the civil society articulated by the networks of the 15-M movement" (Laraña \& Díez, 2012b, p. 218 ${ }^{24}$. In this sense, several analysts and activists, drawing on the Marxist thinker Antonio Gramsci, point to the $15 \mathrm{M}$ as an erosive force or a cultural revolution with a high potential to build up a new cultural hegemony (Fernández-Cuesta, 2013; Fernandez-Savater, 2013a; Lily, 2013; Moreno-Caballud, 2013) ${ }^{25}$.

However, the movement's main groups and organizations do not seem to display a traditional Marxist discourse grounded in 'class struggle', the labor movement, and the working class as a revolutionary force, that should be lead by a political organization "in its struggle against the ruling class" (Laraña \& Díez, 2012b, p. 218) or guided in the process of building up a new cultural hegemony ${ }^{26}$. Actually, it seems that the traditional repertoire of the 'old left' in Spain has been revised and adapted by the $15 \mathrm{M}$ movement to its collective identity mainly based on: i) social change, digital communication and emotions, such as distrust (on politicians and economic elites), outrage, citizen empowerment and hope (\#15MP2P, 2013; Belli \& Díez, 2013; Castells, 2012); ii) the denouncement of the political corruption, the unjust economic order and the financial system, as well as the connivance between political parties and plutocratic groups (Laraña \& Díez, 2012a); and finally, iii) its demand of 'real democracy' and political regeneration and accountability (2012a).

\footnotetext{
${ }^{24}$ This idea comes from Graciela Merigo.

${ }^{25}$ The concept of hegemony refers to "the process by which a ruling group secures the consent of the ruled, this term is identified with the Italian Antonio Gramsci. Writing in prison under Benito Mussolini (1883-1945), Gramsci employed an idiosyncratic vocabulary to avoid censorship. However, this term proved a viable alternative to the more commonly used term ideology, because it describes a process rather than a result of rule [...] Hegemony passes through cycles of emergence, establishment, renewal, and decline, and the hegemonic process will necessarily involve alliances and therefore compromises with groups outside the hegemonic class itself" (Turner, 2006, p. 268).

${ }^{26}$ This statement does not mean that the 'clasical left' has been a homogeneous body in Spain throughout time. In fact, there has been a long tradition of a 'non institutional left', as well as different left-wing organizations, groups and streams (based on Laurence Cox's comments). However, it should be also taken into consideration their subordination to traditional left parties and unions during the Spanish Transition and until the 1980s when pacifist and student -autonomous - movements emerged against the Socialist Government (Laraña, 1999; 2011). Since then, the growing autonomy of social movements in Spain seems to have reached its high level with the emergence of the $15 \mathrm{M}$.
} 


\section{Referencias}

\#15MP2P (2013, July). Encuentro 15MP2P. Una mirada transdisciplinar del 15M. Barcelona, IN3, Unviersidad Oberta de Cataluña. Retrieved from http://civilsc.net/15mp2p

Almeida [bufetalmeida] (2013a, July 5). El eje izquierda-derecha es propio de sistemas informativos televisión-público. En un sistema en red es inoperativo. \#15mP2P [Tweet]. Retrieved from: https://twitter.com/bufetalmeida/status/353108545992011779

Almeida [bufetalmeida] (2013b, July 5). \#15MP2P TT, imagen del momento. [Tweet]. Retrieved from: https://twitter.com/bufetalmeida/status/353128480038330368

Almond, Gabriel A. \& Verba, Sidney (1963). The Civic Culture: Political Attitudes and Democracy in Five Nations, an Analytic Study. Princeton: Princeton University Press.

Álvarez, Klaudia \& Lovaglio, Dario (2013, July). Por una definición del 15m. Una multitud irrepresentable. In \#15MP2P - Encuentro transdisciplinar del 15M. Barcelona.

Belli, Simone \& Díez, Rubén (2013, July). Emociones en la plaza y en la pantalla, in \#15MP2P - Encuentro transdisciplinar del 15M. Barcelona. Retrieved from: www.academia.edu/4054812/ Emociones en la plaza y en la pantalla junt o con D. Simone Belli. 15MP2P Papers and Producciones. Encuentro Tra nsdisciplinar del 15M. Barcelona Programa Comunicacion y Sociedad Civ il Interdisciplnary Institute IN3 UOC codirigido por Manuel Castells julio de 2013

Calvo, Kerman; Gómez-Pastrana, Teresa; Jiménez Sánchez, Manuel \& Mena, Luis (2011). Movimiento 15M: ¿quiénes son y qué reivindican? Colección Zoom Político, Especial 15-M, 2011/4, Fundación Alternativas. Retrieved from: http://www.falternativas.org/en/laboratorio/libros-e-informes/zoompolitico/especial-15-m

Castells, Manuel (2009). Comunicación y Poder. Madrid: Alianza Editorial.

Castells, Manuel (2012). Networks of outrage and hope. Social movements in the Internet Age. Cambridge: Polity Press.

Caute, David (1988). The Year of the Barricades: A fourney Through 1968. New York: Harper \& Row.

Chaves, Pedro (2012). La movilización de los indignados: una explicación sociopolítica. Paideia: Revista de Filosofía y Didáctica Filosófica, 32(94), 141-162. Retrieved from: www.pensamientocritico.org/pedchav0912.pdf

Cicourel, Aaron (1964). Method and Measurement in Sociology. New York: The Free Press.

CIS, ES2920 (2011). Postelectoral elecciones generales, 2011. Nov.11/Ene.12. retrieved from: http://www.cis.es/cis/opencm/ES/1 encuestas/estudios/ver.jsp? $\underline{\text { estudio }=12604}$ 
Cordero-Guzman, Hector R. (2011a). Main Stream Support for a Mainstream Movement: The 99\% Movement Comes From and Looks Like the 99. Retrieved from: occupywallst.org/media/pdf/OWS-profile1-10-18-11-sent-v2-HRCG.pdf

Cordero-Guzman, Hector R. (2011b). 70\% of \#OWS Supporters are Politically Independent. Retrieved from: http://occupywallst.org/article/70-percent-owssupporters-independent

Croteau, David; Hoynes, William \& Ryan, Charlotte (2005). Rhyming Hope and History: Activists, Academics and Social Movement Scholarship. Minneapolis: University of Minnesota Press.

Díez, Rubén (2013, november). An approach to the Spanish 15M and the transnational networks of 'indignados': ideology, identity and method. In International Workshop 'Transnational public participation \& social movement activism', University Nova de Lisboa \& University Institute of Lisbon.

Díez, Rubén (2014, march). From the North to the South, from the East to the West, the struggle continues whatever it takes: Democracy and transnational networks of 'indignados'. In Global Dynamics Seminar: 'Structural Adjustment Comes to Europe', Roskilde University.

Díez, Rubén \& Laraña, Enrique (not published). The Spanish 15-M and the emergence of an international movement: Ethnography, framing and language.

DRY (2011). Real Democracy Now! Manifesto. Retrieved from: http://www.democraciarealya.es/manifiesto-comun/manifesto-english

Durkheim, Emile (1893/2001). La división del trabajo social. Madrid: Akal.

Eyerman, Ron \& Jamison, Andrew (1991). Social movements. A cognitive Approach. Cambridge: Polity Press

Fernandez-Cuesta, Manuel (2013, July 19). Gramsci y la nueva hegemonía cultural. eldiario.es. Retrieved from: http://www.eldiario.es/zonacritica/Gramsci-nuevahegemonia-cultural 6 138296182.html

Fernandez-Savater, Amador (2013a, June 8). Fuerza y poder. Reimaginar la revolución. eldiario.es. Retrieved from: http://www.eldiario.es/interferencias/Fuerzapoder-Reimaginar-revolucion 6 155444464.html

Fernandez-Savater, Amador (2013b, July). Política literal y política literaria. Sobre ficciones políticas y 15M. In \#15MP2P - Encuentro transdisciplinar del 15M. Barcelona.

Gener, Ivan (2011, October 15). No somos ni de izquierda, ni de derechas, somos los de abajo que vamos a por los de arriba. [Flickr]. Retrieved from: http://www.flickr.com/photos/igener/6249096779

Goffman, Erving (1961). Asylums: essays on the social situation on mental patients and other inmates. New York: Anchor Books.

Goffman, Erving (1974). Frame Analysis. Boston: Northeastern University Press.

Gusfield, Joseph (1994). The reflexivity of social movements: Collective Behavior and Mass Society Revisited. In Enrique Laraña, Hank Johnston \& Joseph R. Gusfield (Eds.), New Social Movements. From ideology to Identity (pp. 58-78). Philadelphia: Temple University Press. 
Gutierrez, Bernardo (2013a, July 12). La huelga general de Brasil se ve obligada a compartir espacio con las nuevas protestas. eldiario.es. Retrieved from: http://www.eldiario.es/internacional/general-Brasil-obligada-compartirprotestas 0 152934821.html

Gutierrez, Bernardo (2013b, October 11). Las asambleas populares reinventan la participación política en Brasil. eldiario.es. Retrieved from: http://www.eldiario.es/internacional/asambleas-populares-reinventanparticipacion-Brasil 0 184782265.html

Hardt, Michael \& Negri, Antonio (2000). Empire. Cambridge: Harvard University Press. Hardt, Michael \& Negri, Antonio (2004). Multitude. War and Democracy in the age of Empire. New York: Penguin University Press.

Inglehart, Ronald (1991). El cambio cultural en las sociedades industriales avanzadas. Madrid: Centro de Investigaciones Sociológicas.

Joan [joannomada] (2013, July 5). El \#15m y @LA_PAH se articulan fuera del eje izquierda - derecha. El comun es la finalidad y el hacer y no la ideologia \#15mp2p [Tweet]. Retrieved from: https://twitter.com/joanomada/status/353104374786043904

Klandermans, Bert \&. Staggenborg, Suzanne (2002). Methods of social movement research. Minneapolis: the University of Minnesota Press

LaEneida (2011, May 19). Ni izquierda, ni derecha, arriba o abajo, apaga la tele. [Flickr]. Retrieved from: https://www.flickr.com/photos/chicasalza/5738988514

Langman, Lauren (2013). Occupy: A new social movement. Current Sociology, 61(4), 510-524. http://dx.doi.org/10.1177/0011392113479749

Laraña, Enrique (1999). La construcción de los movimientos sociales. Madrid: Alianza.

Laraña, Enrique (2007). Asociación y modernización social. Las organizaciones voluntarias en España. In José Almaraz Pestaña, Julio Carabaña Morales, Emilio Lamo de Espinosa, Alfonso Pérez-Agote Poveda, Ramón Ramos Torre, Miguel Requena y Díez de Revenga y Marcial Romero López (Comps.), Lo que hacen los sociólogos, libro homenaje a Carlos Moya (pp. 735-754). Madrid: CIS.

Laraña, Enrique (2009). Is Spain a Statist Society? A Research Perspective on Organizations, Reflexivity and Collective Action. Institute for the Study of Societal Issues (ISSI) at the University of California. Retrieved from: http://repositories.cdlib.org/issc/reports/ISSC VS WP 01 Fall

Laraña, Enrique (2011). Los movimientos sociales y la transición a la democracia en España. In Rafael Quirosa-Cheyrouze y Muñoz (Ed.), La sociedad española en la transición. Los movimientos sociales en el proceso democratizador (pp. 63-78). Madrid: Siglo XXI.

Laraña, Enrique \& Díez, Rubén (2010, July). La transformación de una sociedad estatista. Organizaciones voluntarias y cambio social en España. In $X$ Congreso Español de Sociología (Ponencia del Grupo Movimientos Sociales, Acción Colectiva y Cambio Social). Pamplona (UPNA).

Laraña, Enrique \& Díez, Rubén (2012a). Las raíces del movimiento 15-M. Orden social e indignación moral. Revista Española del Tercer Sector, 20, 105-144. Retrieved 
from: https://www.academia.edu/4054737/Las raices del movimientos 15M. Orden social e indignacion moral con Enrique Larana

Laraña, Enrique \& Díez, Rubén (2012b). El aniversario de un movimiento internacional. Continuidad y poder de persuasión colectiva del 15-M. In $\mathrm{M}^{\mathrm{a}}$ Dolores Cáceres y Antonio Lucas (Eds.), Crisis y cambios en la sociedad contemporánea: Comunicación y problemas sociales (pp. 205-229). Madrid: Fragua.

Laraña, Enrique \& Díez, Rubén (2013, July). Las organizaciones reflexivas y el surgimiento de la sociedad civil en España. In XI Congreso Español de Sociología (Ponencia del Grupo Movimientos Sociales, Acción Colectiva y Cambio Social). Madrid (UCM).

Levi, Simona (2013, July). Nuevas virtudes tácticas. Internet, rEvolución y 15M, in \#15MP2P - Encuentro transdisciplinar del 15M. Barcelona.

Likki, Tiina (2012). 15M Revisited: A Diverse Movement United for Change. Colección Zoom Político, número 2012/11. Fundación Alternativas.

http://www.falternativas.org/laboratory/news/presentaciones/nuevo-zoompolitico-2012-11-15m-revisited-a-diverse-movement-united-for-change-18603

Lily, Shangay (2013, May 13). El 15M pasó, la PDLD llegó y Gramsci se quedó. Público.es. Retrieved from: http://blogs.publico.es/shangaylily/2013/05/13/el15m-paso-la-pdld-llego-y-gramsci-se-quedo/

Lobera, Josep \& Sampedro, Victor (2013, July). El 15M: ¿un movimiento transversal? In \#15MP2P - Encuentro transdisciplinar del 15M. Barcelona.

Lopez Iturriaga, Mikel (2013, July 28). Ada Colau: "En España puedes ser un mafioso y disfrutar de reconocimieno oficial". elpais.com. Retrieved from: http://elpais.com/elpais/2013/07/25/eps/1374754845 971730.html

Mannheim, Karl (1936/1954). Ideology and utopia. London: Routledge \& Kegan Paul LTD.

Melucci, Alberto (1989). Nomads of the Present. Philadelphia: Temple University Press.

Melucci, Alberto (1995). The process of collective identity. In Bert Klandermans \& Hank Johnston (Eds.), Social Movements and Culture (pp. 41-63). Minneapolis: University of Minnesota Press.

Milkman, Ruth; Luce, Stephanie \& Lewis, Penny (2013). Changing the subject: $a$ bottom-up account of Occupy Wall Street in New York City. New York: The Joseph S. Murphy Institute for Worker Education and Labor. Retrieved from: http://sps.cuny.edu/filestore/1/5/7/1 a05051d2117901d/1571 92f562221b8041e. pdf

Moreno-Caballud, Luis (2013). Desbordamientos culturales en torno al 15-M. Teknocultura, Revista de Cultura Digital y Movimientos Sociales, 10(1), 101-130. teknokultura.net/index.php/tk/article/view/79

Perugorria, Ignacia \& Tejerina, Benjamín (2013). Politics of the encounter: Cognition, emotions, and networks in the Spanish 15M. Current Sociology, 61 (4), 424-442. http://dx.doi.org/10.1177/0011392113479743

Nearea, Rebecca (2013, September 4). Organized Civil Society, Participatory Institutions and the June Protests in Brazil. Mobilizing Ideas. Retrieved from: 
http://mobilizingideas.wordpress.com/2013/08/06/organized-civil-societyparticipatory-institutions-and-the-june-protests-in-brazil/

Putnam, Robert D. (2000). Bowling alone: the collapse and revival of American community. New York: Simon \& Schuster.

Rey, Ana (2011, May 20). Ni de izquierda, ni derecha, somos los de abajo contra los de arriba. [Flickr]. Retrieved from:

https://www.flickr.com/photos/anarey/5741179417

Sguiglia, Nico (2013, July). Organización Monstruo. Biopolítica y nueva institucionalidad en el ciclo 15M, in \#15MP2P - Encuentro transdisciplinar del $15 M$. Barcelona.

Snow, David A. \& Benford, Robert D. (1988). Ideology, Frame Ressonance and Participant Mobilization. In Bert Klandermans, Hanspeter Kriesi and Sidney Tarrow (Eds.), International Social Movement Research (vol. 1, pp. 197-217). Greenwich: JAI Press.

Snow, David A. \& Benford, Robert D. (1992). Master Frames and Cycles of Protest. In Aldon D. Morris \& Carol McClurg Mueller (Eds.), The Frontiers in Social Movement Theory (pp. 133-155). London: Yale University Press.

Tarrow, Sidney (1994), Power in movement: Social Movements, Collective Action and Politics. New York: Cambridge University Press.

Tecnopolítica [Tecnopolítica_] (2013a, July 5). @casiopeaexpres cita a Lenin para demostrar que no somos ni de izquierdas ni de derechas \#15mp2p [Tweet]. Retrieved from: https://twitter.com/Tecnopolitica /status/353097977759420416

Tecnopolítica [Tecnopolítica_] (2013b, July 5). La mayoría de identidades colectivas \#15m como @la_pah se niegan a definirse en el eje Izquierda/Derecha \#15mp2p [Tweet]. Retrieved from: https://twitter.com/Tecnopolitica/status/353104219051528194

Tilly, Charles (1991). Grandes estructuras, procesos amplios, comparaciones enormes. Madrid: Alianza Universidad.

Toret [toret] (2013, July 5). Tanto @LA_PAH como el \#15M se sitúan más allá del eje de izquierda y derecha @galapita en \#15mP2P [Tweet]. Retrieved from: https://twitter.com/toret/status/353104337330905088

Turner, Ralph (1994). Ideology and Utopia After Socialism. In E. Laraña, H. Johnston \& J. Gusfield (Eds.), New Social Movements. From ideology to Identity (pp. 79-100). Philadelphia: Temple University Press.

Turner, Bryan (2006). The Cambridge dictionary of Sociology. Cambridge England New York: Cambridge University Press.

Tocqueville, Alexis de (1840/1985), De la Democracia en América. Barcelona: Orbis.

Virno, Paolo (2014). A grammar of the multitude. For an analysis of contemporary forms of life. Cambridge: The MIT Press.

Zald, Mayer N. \& McCarthy, John D. (1987). Social Movements in an Organizational Society. New Brunswick, NJ: Transaction Books. 
Zapata, Guillermo (2013, July). La democracia como bien común: La nueva política en el campo 15M. In \#15MP2P - Encuentro transdisciplinar del 15M. Barcelona.

\section{(9) (1)}

Este texto está protegido por una licencia Creative Commons 4.0

Usted es libre para Compartir — copiar y redistribuir el material en cualquier medio o formato- y Adaptar el documento - remezclar, transformar y crear a partir del material - para cualquier propósito, incluso comercialmente, siempre que cumpla la condición de:

Atribución: Usted debe reconocer el crédito de una obra de manera adecuada, proporcionar un enlace a la licencia, e indicar si se han realizado cambios . Puede hacerlo en cualquier forma razonable, pero no de forma tal que sugiera que tiene el apoyo del licenciante o lo recibe por el uso que hace. 